\title{
CONTEMPORARY LEGAL ISSUES IN ELECTRONIC COMMERCE IN NIGERIA
}

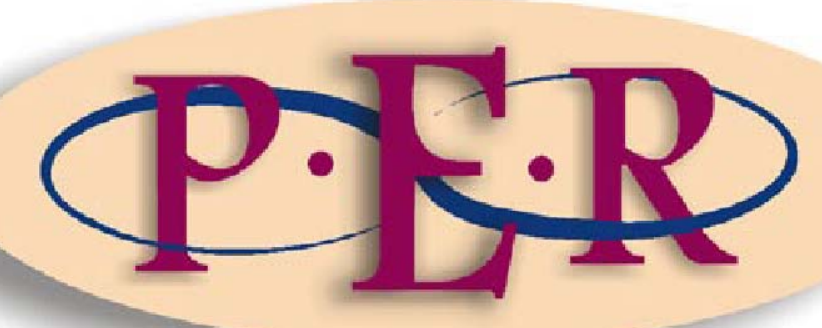

2008 VOLUME 11 No 3 
CONTEMPORARY LEGAL ISSUES IN ELECTRONIC COMMERCE IN

NIGERIA

TI Akomolede*

\section{Introduction}

There is no doubt that the internet has added a great deal to the quality of human life in the contemporary world. It has knitted the world together as a global village. Many difficulties which hampered international and even national commercial transactions in the past have now been consigned to the dust-bin of history. The emergence of electronic commerce has occurred as a result of the development of the internet, and commercial transactions are conducted through it between parties from different parts of the world who may never see themselves in their lifetimes. However, the emergence of electronic commerce has also brought with it a number of legal and socio-economic issues, especially in developing nations such as Nigeria, which issues pose significant challenges to the legal regime of electronic commerce in those countries. This paper examines these legal issues within the context of the current legal and regulatory framework for electronic commerce in Nigeria.

\section{Definitional perspectives}

E-commerce is the buying and selling of goods and services through the internet. ${ }^{1}$ It has also been defined as the sharing of business information, the maintaining of business relationships, and the conducting of transactions by means of telecommunication networks. ${ }^{2}$ The United Kingdom Cabinet Office defines it as the exchange of information across electronic networks at any

* LL B(Hons) BL LL M MPhil PhD ACIS, Senior Lecturer, Department of Business and Industrial Law, Faculty of Law, Olabisi Onabanjo University, Nigeria.

1 Chaffey E-Business 7.

2 Zwass Zwass IJEC 14. 
stage in the supply chain, whether within an organisation, between businesses, between businesses and consumers, or between the public and private sectors, whether paid or unpaid. ${ }^{3}$

The scope of electronic commerce is wide and includes all electronically mediated transactions between an organisation and a third party. It is not restricted solely to the actual buying and selling of products, but includes presale and post-sale activities. ${ }^{4}$ In more liberal terms, once a contract of sale is effected between a seller and a buyer using such electronic means as the electronic mail, regardless of distance or any geographical barrier, it is within the province of electronic commerce. ${ }^{5}$

The objectives of e-commerce are legion. They include the facilitation of international co-operation through trade, making goods and services available to consumers all over the world irrespective of distance, the expansion of the consumer base for manufacturers or producers of goods and services, and a reduction in the costs of service delivery by delivering these electronically. ${ }^{6}$ The objectives of e-commerce underscore its importance in the emerging global community. With the effect that today's consumers are able to have access to goods and services in the remotest parts of the world without having to see the sellers. The traditional buying and selling process is being gradually replaced by internet trading, especially in more advanced countries. ${ }^{7}$

The major significance of e-commerce thus lies in the fact that it encourages a single world trading system which is facilitated by access through electronic means to goods and services from different parts of the world. This has led to the emergence of uniform regulatory rules on internet governance to ensure the

\footnotetext{
United Kingdom Cabinet Office, 1999.

Kalakota and Whinston Electronic Commerce 69.

See Kosiur Understanding Electronic Commerce 5.

See Chaffey E-Business 16.

See Bali Information Technology and the Law 53
} 
homogeneity of the conditions under which transactions are made to suppliers or sellers and consumers of goods and services through the internet. ${ }^{8}$

Consumers in e-commerce are faced with a number of risks arising from the general lack of understanding of the operations of the internet. This has been compounded by a number of legal issues which have been largely taken care of in more advanced and sophisticated countries, but which issues are still being grappled with in developing countries such as Nigeria, where internet trading is something fairly new. These issues include the extent to which the communication between the parties is protected (data protection), the formation of a contract on the internet, the legal means of effecting payment in ecommerce, which court will assume jurisdiction in the event of a dispute between parties to an internet contract, and what law or laws will govern the transactions. Is it the law of the seller or that of the buyer or consumer? Other issues relate to cyber crimes that are threatening e-commerce, and also the mode of proving internet-related transactions. An examination of the foregoing issues vis-à-vis the position of the law in Nigeria presently is the focus of this paper.

\section{Data protection in e-commerce}

In the English case of $R v$ Brown ${ }^{9}$ Lord Hoffman lucidly captured the thrust of the problems associated with data protection in e-commerce as follows:

Vast amounts of information about everyone are stored on computers, capable of instant transmission anywhere in the world and accessible at the touch of a keyboard. The right to keep oneself to oneself, to tell other people that certain things are none of their business is under technological threat.

8 Eg, such organisations as The Internet Corporation, The Internet Society, The Internet Engineering Task Force, and The Worldwide Web Consortium were all established to achieve uniformity of terms and conditions on the Internet. 
Trading on the internet is through the transmission of electronic data from the suppliers or producers of goods and services to the buyers, and vice versa. In view of the openness and accessibility of the internet the protection of such data has been a constant source of concern for internet users and consequently has remained a threat to e-commerce. ${ }^{10}$

A number of jurisdictions have therefore come up with protective legislation. ${ }^{11}$ There is no legislation on the protection of data presently in Nigeria, and the situation portends a great danger for consumers in e-commerce. It is suggested that a cue be taken from the United Kingdom, where there are principles that govern the protection of the data or communication of the parties in all internet transactions. ${ }^{12}$

\section{$4 \quad$ Formation of contract on the internet}

The determination of the moment when a contract can be said to have come into existence on the internet, giving rise to the existence of rights and duties as between the parties, has been one of the vexed issues in e-commerce. In contrast, traditional commercial transactions do not pose any significant problem because there are elaborate common law and statutory rules that govern such transactions.

The special nature of internet contracts has made most of the common law rules applicable to commercial contracts inapplicable to such contracts. For example, websites are designed in such a way as to constitute an invitation to make an offer and not situations of real offers by the web owners. However, in sales over the internet, both the display and the actual sale are often fused. ${ }^{13}$

10 See Gringas and Nabarro Laws of the Internet 249.

11 For instance, the Data Protection Act 1984 was enacted in the UK and it harmonised earlier legislation, policies and directives meant to protect communication through the Internet. See also the Electronic Communications Privacy Act 1988 in the USA.

12 See the provisions of the Data Protection Act 1984 (UK).

13 See the case of Harvela Investments v Royal Trust Company of Canada [1986] AC 207. 
Therefore, the seller or website owner must design the web page in such a way that it must clearly indicate that the information contained on the web in respect of a particular product or service is meant to elicit an offer and is not in itself an offer. It is thus important for the owner of a website to err on the side of caution in creating a web invitation, and one method of doing this is to state that he will not be bound by any communication from a third party except if the owner accepts such communication and informs the third party accordingly. ${ }^{14}$

The analogy has always been to liken a website to a shop in such a way that the product information on the website constitutes an invitation to make an offer. While it has been held that a justification for not holding shops as making offers is to ensure that if the shop's stock is depleted, a willing consumer cannot sue the shop owner for damages. ${ }^{15}$ The argument has also been made that a website is not offering physical goods for sale, and as such it is difficult to accept that supplies can be exhausted, because digital products supplied on the internet are infinite in supply. ${ }^{16}$

Even though there is no direct decided authority on the above point known to me presently, it accords with good sense and commercial necessity that the web owner should clearly indicate if the display or advertisement of his goods on the web amounts to a direct offer to whoever comes in contact with the site, or an invitation to make an offer. The approach would save a lot of time and expense that would otherwise have been wasted on frivolous or unnecessary litigation.

Offers in electronic commerce are made electronically. E-mails are not as instantaneous as faxes and telephone calls. An e-mail message is sent to a services provider who in turn delivers it to the box of the receiver. E-mails can be misaddressed or delayed by any server on the way, and may not even be collected or read until some time after their delivery. It may thus be difficult to

14 See Gringas and Nabarro Laws of the Internet 15.

15 See Esso Petroleum v Customs and Excise Commissioners [1976] 1WLR 1, 11.

16 See Gringas and Nabarro Laws of the Internet 16 
know when an e-mail was actually read, to determine when an offer was made or acceptance communicated. According to Gringas, ${ }^{17}$ the best practice legally is to make any offer by e-mail subject to a date on which the offer will lapse. An objective date and time must be specified. If no intention is shown as to the lifespan of the offer, the courts would imply that the offer lapses after a reasonable time. ${ }^{18}$

The general rules applicable to the acceptance of offers are also applicable to the acceptance of offers made on the internet. However, where the offer is through e-mail, the receipt of such mail by the website owner will not constitute the acceptance of the terms of such an offer. It has also been held that e-mail message sent in reply to an e-mailed offer stating the recipient's intention to reply in due course will not be an acceptance. ${ }^{19}$

A contractual situation that is often peculiar to the internet is the consideration needed to cement a web-based contract. The use of digital cash in exchange for goods or services raises issues not of consideration but of performance of a contract in a web-wrap contract which is an agreement at the front of a website which purports to bind the browsers to a contract should they proceed to browse the site. Promises to pay over the internet are enough to form the consideration to create a contract, in the same way as such promises would lead to enforceable contracts in normal commercial transactions. ${ }^{20}$

Contractual intention is also essential to entering into internet or web-based contracts. The presence of a contractual intention is even more important in ecommerce, because more often than not only one human being is involved in the communication, with programmed computers or machines at the other side. It is settled that contracts can be made with machines, and it is of no legal

17 See Gringas and Nabarro Laws of the Internet 16

18 See Chanco Leasing SPA v Rediffusion [1987] 1 FTLR 207. Also, Quenerdine v Cole (1883) 32 WL 185.

19 See DTM v Hydranautics [1981] 2 Lloyd's Report 2211.

20 See Bradesh v Arthur (unreported), reviewed in Reporter 1999 IBAQ 18. See also Specht $\checkmark$ Netscape [2002] (unreported), as reviewed by Bali Information Technology and the Law. 
consequence that a machine physically completed the contract. ${ }^{21}$ However, in most cases the courts look objectively into the circumstances of each case to determine whether a contract has been made or not. Thus, in determining the requisite intention the court applies an objective test as against a subjective one. $^{22}$

\section{$5 \quad$ Payment system in e-commerce}

Making payment for goods and services bought through the internet poses unique problems because of the fact that the parties may be thousands of kilometers apart. The problems associated with internet payment are in relation to the inability of the internet to guarantee the safety of such payments and the possibility of duplicating payment, since a computer could potentially become a forger of digital banknotes. ${ }^{23}$

Goods and services bought or supplied through the internet can be paid for through the internet in the same way that the internet can be used to make offers and accept offers. ${ }^{24}$ Vendors or sellers often insist on receiving and validating payments before providing services or releasing goods to customers, and it is therefore suggested that terms to this effect should be incorporated as part of the standard form agreements in e-commerce.

Popular methods of effecting payments for goods bought through the internet include the use of credit cards, smart cards, digital or electronic cheques or cash, and debit cards. The use of credit cards is still not very popular in developing countries, because e-commerce itself is still at its infancy, and the practice is therefore for the sellers to obtain bank guarantees in such

21 See Thornton v Shoe Lane Parking [1971] 2 QB 163, Edwards v Skyview [1964] 1 WLR 399, Smith v Hughes (1871) LR 6 QB 597.

22 See Shaktas On-line Services v Burrough [1999] (unreported), reviewed in Reporter 1999 SBJ 6. Also, Smith v Hughes (1871) LR 6 QB 597.

23 See Gringas and Nabarro Laws of the Internet 31.

24 See Lynch and Lundquist Digital Money 38. 
transactions. ${ }^{25}$ If the goods are supplied and payment is not forthcoming through the bank's guarantee, the seller has a right of action against the issuing bank that has guaranteed payments. ${ }^{26}$

There are many problems associated with obtaining bank guarantees in Nigeria, for payments in respect of goods bought internationally or through the internet. This has greatly hampered the development of e-commerce. However, with the increasing level of sophistication in information technology and the development of the telecommunication sector, the use of credit card and other payment facilities in e-commerce will become increasingly popular, and in the process, some of the problems associated with payment for goods and services in e-commerce will be reduced. ${ }^{27}$

\section{Jurisdiction and choice of law issues}

The issue of jurisdiction is a crucial one in e-commerce. The question has always been which court assumes jurisdiction in resolving a dispute arising from a contract between the parties, in view of the fact that the parties may be residing in different jurisdictions with different legal systems.

The issue basically is one of Private International Law, and the relevant Convention is the Brussels Convention on Jurisdiction and Enforcement of Judgment in Civil and Commercial Matters. ${ }^{28}$ The Convention is applicable to those countries that have ratified it and incorporated its provisions into their municipal laws. However, it is doubtful if the Convention has been ratified in Nigeria, as the writer could not find any evidence of its ratification.

25 Value cards are however widely used in Nigeria for local purchases in supermarkets, petrol stations, etc.

26 See, generally, Dinakin 1982 Law and Practice of International Trade 36.

27 See Hofacker Internet Marketing 81.

28 See Brussels Convention on Jurisdiction and Enforcement of Judgments in Civil and Commercial Matters 1958. 
In relation to internet contracts, the general rule is that jurisdiction is determined by reference to the place or country where the contract is performed. ${ }^{29}$ Where there are many jurisdictions where the contract is performed, the relevant jurisdiction is the jurisdiction where the dispute arises. The place of domicile may also determine the court that will have jurisdiction. Where the parties are domiciled in a contracting state under the Brussels Convention, the rules of the Convention are applicable, while the rules of common law are applicable where the parties are not domiciled within a contracting state. Also, a person's domicile must be assessed from the state's legal perspective to determine whether or not he is domiciled in a contracting state. ${ }^{30}$

There is a reversal of the general rule above in relation to consumer products, in that consumers are allowed to sue and be sued in their home states. ${ }^{31}$ The implication therefore is that there will be a frequent reversal of the general rule in favour of consumers, namely that litigation will take place only where the consumers reside, since most website owners are either suppliers of goods and services or professionals.

The trend in e-commerce has therefore been to paste on the website that an agreement resulting from viewing a website is not a contract for the sale of goods or supply of services. This is obviously done to avoid the rule in favour of consumers. It has, however, been held that classification of a contract as a contract of sale of goods or supply of services should be determined by examining the terms of the contracts to discover the substances. ${ }^{32}$ The courts have the powers to look at the content and substance of a transaction in the event of a dispute, to determine whether it is contract of sale of goods or supply of services. ${ }^{33}$

29 See Davies Contract Formation 100.

$30 \mathrm{Eg}$, for internet contracts made in the UK, the provisions of s 41(7) of the Civil Jurisdiction and Judgement Act 1982 are applied to determine whether the defendant is domiciled outside the contracting state.

31 See art 13 and 14 of the Brussels Convention. Also, s 44, Civil Jurisdiction and Judgement Act 1982 (UK).

32 Robinson v Graves [1935] 1 KB 579, 587

33 See generally the obiter dictum of Sir lain Glidewell in St Alban's City and District Council v International Computers [1996] 4 All ER 481, 493, where he opined that a transfer of a 
The postal rule is inapplicable to an e-mail contract. The place where the e-mail contract is made is the acceptor's place, and that is the relevant place for purpose of jurisdiction. ${ }^{34}$ The rules on a worldwide website differ from the rules relating to an e-mail contract in that there is no binding contract until notice of acceptance is received by the seller and the contract is made where the seller receives notification of the acceptance, which is equally relevant for purposes of jurisdiction.

A corollary of the vexed issue of jurisdiction in e-commerce is the choice of law to be applicable in disputes arising from consumer contracts concluded over the internet. The complexity involved in the choice of applicable law has been described as follows:

The question of choice of law... is particularly difficult in the case of International computer networks where, because of dispersed location and rapid movement of data and geographically dispersed processing activities, several connecting factors could occur in a computer manner involving elements of legal novelty. 35

A learner author has also observed as follows:

There are still more difficulties with regulation of cyberspace by the laws of a single jurisdiction. It is not just that national law is difficult to apply and enforce given the inherently transnational nature of the internet. It is also sometimes impossible to discern what country's laws would be most appropriately applied. 36

Where parties to the internet contract are citizens of countries that have ratified the Rome Convention, ${ }^{37}$ then the provisions of the Convention would be applicable to determine which law to apply in disputes between the parties. The Convention allows the parties to agree $a b$ initio on the law that will be

programme to a computer by a third party did not constitute a transfer of goods, as there was no title passed between them.

34 See Denning LJ, in Entores v Miles Far East Corporation [1953] 2 QB 327, 335.

35 See OECD Explanatory Memorandum and Guidelines on the Protection of Privacy and Transborder Flows of Personal data, 1980 quoted in Gringas and Nabarro Laws of the Internet 45.

36 See Edwards Introduction.

37 The Rome Convention on the Law Applicable to Contractual Obligations 1980. 
applicable to whatever dispute may arise from the transaction, and where no provisions are made then the provisions of the Convention are applicable.

It is important to emphasise, however, that freedom of contract is an established principle in the Law of Obligations and that the parties to an internet contract can therefore agree on the terms and conditions of the contract including the choice of laws to govern the transactions. ${ }^{38}$ However, this is easier in contracts that are not standard form contracts. Where the parties have contracted outside the provisions of the Convention by agreeing on the applicable law to govern their transactions, the complexities of determining what should be the choice of applicable law are entirely avoided, and this is the most plausible approach in commercial transactions over the internet.

\section{$7 \quad$ Evidential issues}

The emergence of e-commerce and its growing popularity have provoked fundamental evidential issues especially in relation to the proof of transactions conducted through the internet. The peculiarity of these issues and the confusion that has also greeted their interpretation by the courts have exposed the inability of the Nigerian Law on Evidence to cope with the admissibility of the avalanche of electronically-generated evidence that is the hallmark of electronic commercial transactions. ${ }^{39}$

E-commerce transactions are paperless transactions made through magnetic materials such as tapes or disks. These are in contradistinction to paper-based transactions that are embodied in a permanent form and typically expressed in

38 See Nnaemeka-Agu, JSC (as he then was) in African Petroleum $v$ Owodunni [1991] 8 NWLR (pt 210) 351. But see the provisions of s 4 of the Supply of Goods (Implied Terms) Act 1973 (UK) where a supplier's freedom to limit terms is now completely abolished. The act provides full protection for buyers in consumer transactions and qualified protection in non-consumer transactions.

39 See generally Osinbajo 1990 Jus 11 
words and figures usually authenticated by signatures. Such transactions can therefore not be altered without an alteration on the face of the document. ${ }^{40}$

One of the greatest challenges facing the courts in Nigeria is the admissibility of computer-generated evidence, in view of the rule that a party must give the best evidence of facts that are in issue before the courts. ${ }^{41}$ In the context of ecommerce, information fed into the computer and posted on the websites of sellers and suppliers of goods and services, when retrieved from the web, would only be copies of such information and at best would be hearsay evidence. The communication between the parties would also be copies as against originals when downloaded from the internet, and for it to be admitted it would have to be put in under any of the exceptions to section 91 of the Evidence Act. ${ }^{42}$

Various sections of the Evidence Act have been explored with a view to determining whether any of them could accommodate the admissibility of computer-generated evidence as an exception to the hearsay rule. These sections include sections 33(b), 38, 39 and 91. These sections have, however, been found to be grossly inadequate for the admissibility of computergenerated evidence, despite the expression of willingness by the courts to interpret the relevant provisions of the Evidence Act liberally. ${ }^{43}$

However, much more progress has been made in the English and American jurisdictions in the admission of computer-generated evidence through specific legislation on computer evidence and judicial activism. For example, in the US case of King $v$ State Ex Rel Murdock Acceptance Corporation, ${ }^{44}$ the court admitted in evidence a computer printout tendered by the plaintiffs which showed the amount owed to them by the defendant. The clerks who accepted

40 See Bender Computer Law Journal 703.

41 This is known as "The Best Evidence Rule" and is contained in s 77 of the Nigerian Evidence Act 1945 (hereafter the Evidence Act). See also Subramanian $v$ Public Prosecutor [1956] WLR 965, 969.

42 See Osinbajo 2004 CLE Workshop Series 21.

43 See the judgment of the Supreme Court in Yesufu v ACB [1976] 4 SC 1, 16, Anyeabosi $v$ RT Briscoe [1987] 3 NWLR 84.

44 King v State Ex Rel Murdock Acceptance Corporation [1996] 22 F2d 39. 
the payments were neither called, nor were the original records in the branch offices of the corporation produced. The court nevertheless admitted the documents and extended the exception to the hearsay evidence to cover computer records. In a bold display of judicial activism the court declared as follows:

The expenditure which the entire commercial world recognizes as safe shall be sanctioned and not discredited by the courts of justice. $^{45}$

In the Australian jurisdiction, the issue of the admissibility of computergenerated evidence is now governed by legislation. ${ }^{46}$ Thus, by the provisions of section 59(1) of the South Australian Evidence Act, computer outputs are now admissible in both civil and criminal proceedings.

In Nigeria, the review of the Evidence Act made by the Nigerian Law Reform Commission is pending before the National Assembly. The Draft Law makes fundamental changes to the existing rules of evidence in relation to computergenerated evidence, but only in respect of civil proceedings. ${ }^{47}$ However, it is suggested that the provisions of the Draft Law should be extended to cover criminal proceedings when eventually it is enacted into law. The foregoing suggestion is very important in view of the increasing rate of cyber criminality and fraudulent practice that is threatening electronic commerce.

\section{Cyber crimes and e-commerce}

Cyber crimes pose many challenges to electronic commerce and have indeed made internet transactions insecure and vulnerable to manipulation by persons who are not parties to such transactions. The extent to which internet crime has

45 Ibid, 48.

46 See s 59(1) South Australian Evidence Act 1929 which copied s 5 of the Evidence Act 1965 (UK).

47 The Draft Law which copied the provisions of the English Civil Evidence Act 1964 provides in its $\mathrm{s} 84$ that in any civil proceedings statements contained in a document produced by a computer shall be admissible as evidence of any fact stated in it of which direct oral evidence would be admissible. 
ravaged the commercial world was succinctly captured by a learned author as follows:

It is also predictable that the proliferation of commerce on the internet will be matched by an expansion of crime on the internet. The rise in the use of digital cash and credit cards over the internet provides a greater incentive to hack than ever before. ${ }^{48}$

Conceptually, internet crime means the commission of unlawful acts using the computer either as a tool or a target, or as both. ${ }^{49}$ It is not defined in any legislation in Nigeria. ${ }^{50}$ The most common internet crimes include hacking and cracking, identity theft, the sale of illegal or stolen articles on the internet, packet sniffing, and the creation of malicious codes such as viruses. These offences are crimes in most advanced countries because of statutory regulations. $^{51}$

In Nigeria, however, these activities are not crimes, because there is no legislation in the country that makes them unlawful. ${ }^{52}$ Herein lies the helplessness of consumers in electronic commerce in Nigeria, who may be victims of one or more of these cyber crimes. The solution to cyber crimes in Nigeria is still at the stage of a Draft Law which is presently pending before the National Assembly.

The Draft Law addresses most of the issues that have been identified as constituting crimes in cyberspace, and which consequently threaten electronic commerce. It contains provisions that are similar to or the same as the relevant provisions of the laws on this subject matter in the advanced jurisdictions. The problems and general trepidation associated with cyber crimes will be reduced

48 Gringas and Nabarro Laws of the Internet 211.

49 See Wall Crime and the Internet 5 as quoted by Adebiyi 2001 JCMF.

50 The closest definition is contained in the Telecommunication and Postal Offences Act 1995, which is in relation to telecommunication and postal matters.

$51 \mathrm{Eg}$, they are crimes in the USA by virtue of the provisions of Electronic Communications Privacy Act 1988 and Computer Fraud and Abuse Act 1991. In Britain, they are crimes by virtue of the provisions of the Computer Misuse Act 1990.

52 There is no penal legislation that makes them an offence directly or indirectly. 
when the Draft Law is eventually enacted into law to pave way for the emergence of a more friendly and protective cyberspace.

\section{$9 \quad$ Legal and regulatory framework of e-commerce in Nigeria}

Electronic commerce is still emerging in most developing nations and Nigeria is not an exception. There is therefore no elaborate legal and regulatory framework for electronic commerce in Nigeria presently. The fact should, however, be mentioned that as e-commerce is a species of commercial transactions, though a special one, there are pockets of commercial legislation and decided cases that directly or indirectly affect it in Nigeria. ${ }^{53}$

On the international scene, a major recognition and regulation of electronic commerce began with the adoption of the UNCITRAL Model Law on Electronic Commerce in $1996 .{ }^{54}$ A cardinal aim of the Model Law was to ensure that the practices of Member States in the area of electronic commerce, as an emerging practice in commercial transactions, should be uniform and of acceptable standard. Thus, Member States were enjoined to enact laws and institutions that conformed substantially to the provisions of the Model Law.

In Nigeria concrete efforts at regulating e-commerce-related activities are still at the stage of Draft Bills before the National Assembly. The relevant bills are the Nigerian Bill on Cyber Crimes and the Electronic Transactions Bill, which is modeled on the UNCITRAL Model Law on e-commerce. The Bill provides for the validity of contracts, matters of evidence, electronic signatures and payment systems, amongst other issues. ${ }^{55}$ The Draft Bill on Cyber Crimes provides the legal and institutional framework for combating cyber crime in Nigeria and

$53 \mathrm{Eg}$, the Sale of Goods Act 1979 and laws in the states, Price Control Act 1990, Preshipment of Imports Act 1993, and Pre-shipment of Exports Act 1996, Trade Malpractices (Miscellaneous Offences) Act 1992, Weight and Measures Act 1977, etc.

54 UNCITRAL is an arm of the UN Organisation and has a mandate to harmonise and promote International Trade Law. The Model Law on Electronic Commerce was adopted on 12 June 1996.

55 See eg, s 6, 7, 9 and 11 of the Draft Bill on Electronic Transactions. 
ensuring cyber security. Provisions are also made for payment of compensation to victims of cyber crimes. The Bill also makes provisions for the establishment of a Cyber Crime and Cyber Security Agency, which is given wide powers to investigate, arrest and prosecute cyber crimes.

It is also important to note the Nigerian National Policy on Information Technology (IT), which has as one of its numerous objectives the cultivation of a culture of electronic commerce which makes business transactions easy, quick and cost effective for both national and international transactions. ${ }^{56}$ The implementation of the IT policy is the responsibility of the National Information Technology Development Agency (NITDA), whose mandate includes the establishment of a National Electronic Commerce Council (NECC) to govern all electronic commerce affairs in Nigeria and to facilitate international trade through an e-commerce infrastructure. ${ }^{57}$

There is no doubt therefore that with the identified developments in electronic commerce in Nigeria, especially the emerging legal and regulatory framework, most of the challenges facing it presently will sooner, rather than later pale into oblivion.

\section{Concluding remarks and the way forward}

Electronic commerce is no doubt a budding phenomenon in commercial transactions in Nigeria and it has been amply demonstrated by this paper that because of its peculiar nature and idiosyncrasies coupled with the abysmally low level of technological development in Nigeria, it is imbued with many problems which have left the consumers in e-commerce gasping for protection. However, given the speed with which the internet is permeating commercial transactions in Nigeria, especially in the banking and telecommunications sectors of the economy, the best that can be suggested is that the legal issues

56 The Nigerian IT policy was developed in 2005 in Nigeria and has a myriad of objectives which include the development and sustainability of electronic commerce in Nigeria.

57 See ch 8(3)(vii) on Trade and Commerce. 
and problems presently confronting e-commerce in Nigeria should be addressed directly and expeditiously, in the interests of the teeming population of Nigerian consumers.

This can be achieved only by pressurising the National Assembly into enacting the various electronic commerce-related bills before it into law, and establishing appropriate institutions for monitoring electronic commerce in Nigeria. When this and other measures suggested in this paper have been taken, the country would have been positioned to tap the avalanche of benefits that would derive from the use of the internet for commercial transactions. 


\section{Bibliography}

Adebiyi 2001 JCMF

Adebiyi T "Internet/Computer Related Crimes in Nigeria" 2001 (2) Journal of Capital Market and Finance

Akomolede 2004 Brainfield LJ

Akomolede $\mathrm{Tl}$ "Economic and Philosophical Foundations of Consumer

Protection: An Overview" 2004 Brainfield Law Journal 101-109

Akomolede 2005 FQLR

Akomolede TI "An appraisal of the Institutional and Regulatory Framework for Consumer Protection in Nigeria" 2005 Fountain Quarterly Law Journal 141-149

Akomolede 2005 Ikeja BJ

Akomolede $\mathrm{Tl}$ "Jurisdiction, Choice of Laws and The Legal Protection of The Consumer In E-Commerce: An Overview" 2005 Ikeja Bar Journal 200205

Akomolede 2006 Ikeja BJ

Akomolede TI "Legal Analysis of Formation of Contracts in E-Commerce" 2006 Ikeja Bar Journal 225-240

Akomolede 2008 Igbinedion ULJ 157-164

Akomolede TI "Evidential Issues in E-Commerce in Nigeria: An Overview" 2008 Igbinedion University Law Journal 157-164

Akomolede and Oladele 2005 Ikeja BJ

Akomolede TI and Oladele PO "Legal Analysis of Taxation and Modes of Payment in E-Commerce" 2005 Ikeja Bar Journal 7-11

Allen and Fjermestad 2001 Logistics IM

Allen E and Fjermestad J "E-Commerce Marketing Strategies: Framework And Case Analysis" 2001 (4) Logistics Information Management 14-23 
Arnold-Moore 1994 JLIS

Aranold-Moore T "Legal Pitfalls in Cyberspace" 1994 Journal of Law and Information Science 165-178

Arnott and Bridgewaters 2002 JMIP

Arnott D and Bridgewaters C "Internet Interaction and implications for marketing" 2002 Journal of Marketing Intelligence and Planning 86-95

Bali Information Technology and the Law

Bali O Information Technology and The Law (Legal Digest Publishing Lagos 2002)

Bender Computer Law Journal

Bender D "Computer evidence law: scope and structure" 1979 Computer Law Journal 699-714

Berryman 1998 McKinley Quarterly

Berryman K "Electronic Commerce Three Emerging strategies" 1998 McKinley Quarterly 152-159

Bickerton CyberMarketing

Bickerton P CyberMarketing $2^{\text {nd }}$ ed (Butterworth Heinemann Oxford 2000)

Brodersen 1997 Intertax Journal

Brodersen C "International Tax Issues in Cyberspace: Taxation of Cross border Electronic Commerce" 1997 Intertax Journal 120-142

Cavazos Cyberspace

Cavazos M Cyberspace and the Law (MIT Press Cambridge 1994)

Chaffey E-Business

Chaffey D E-Business and E-Commerce Management $2^{\text {nd }}$ ed (Prentice Hall Harlow 2003)

Chaffey Internet Marketing

Chaffey D Internet Marketing: Strategy, Implementation and Practice $2^{\text {nd }}$ ed (Prentice Hall Harlow 2003) 


\section{Chaston E-Commerce Marketing}

Chaston I E-Commerce Marketing $2^{\text {nd }}$ ed (McGraw-Hill Maiden 2000)

Damanpour E-business

Damanpour F E-business, E-commerce, Evolution, Perspective and Strategy (Hart publishing London 2001)

Davies Contract Formation

Davies O "Contract Formation on the Internet: Shattering a Few Myths" in Edwards L and Waelde C (ed) Law and the Internet (Hart Publishing Oxford 1997)

Dinakin 1982 Law and Practice of International Trade

Dinakin Y "Forms and Procedure of Import Export trade in Nigeria" 1982 (3) Law and Practice of International Trade 30-42

Edwards and Anor Introduction

Edwards $L$ "Introduction to the Law and Internet" in Edwards $L$ and Waelde C (ed) Law and the Internet (Hart Publishing Oxford 1997)

Evans and Wurster 1999 Harv BR

Evans P and Wurster T "Getting real about Virtual Commerce" 1999 Harvard Business Review 84

Fabunmi Commercial Law

Fabunmi JO Commercial Law in the Context of Economic Development:

The Nigerian Experience (OAU Press Ile-Ife 1987)

Ghosh 1998 Harv BR

Ghosh S "Making business sense of the Internet" 1998 Harvard Business Review 126-135

Gringas and Nabarro Laws of the Internet

Gringas C and Nabarro N The Laws of the Internet (Butterworths London 1977)

Hofacker Internet Marketing

Hofacker C Internet Marketing (Wiley New York 2001) 
Kalakota and Whinston Electronic Commerce

Kalakota R and Whinston A Electronic Commerce A Manager's Guide $3^{\text {rd }}$ ed (Addison Wesley Reading 1997)

Kosiur Understanding Electronic Commerce 5

Kosiur D Understanding Electronic Commerce (Microsoft Press Redmond Wash 2000)

Lloyd Information Technology Law

Lloyd IJ Information Technology Law $2^{\text {nd }}$ ed (Butterworths London 2001)

Lloyd Legal Barriers

Lloyd IJ "Legal Barriers to Electronic Contracts" in Edwards L and Waelde C (ed) Law and the Internet (Hart Publishing Oxford 1997)

Lynch and Lundquist Digital Money

Lynch DC and Lundquist L Digital Money (Wiley New York 1996)

McDonnell Taxation

McDonnell C "Taxation and Electronic Commerce" in Edwards $L$ and

Waelde C (ed) Law and the Internet (Hart Publishing Oxford 1997)

Mclvor 2000 BPMJ

Mclvor R "Electronic commerce: Re-engineering the buyer supplier

Interface" 2000 (6) Business Process Management Journal 122-131

Osinbajo 1990 Jus

Osinbajo $Y$ "Admissibility of Computer Generated Evidence under Nigerian Law" 1990 Jus 11-20

Osinbajo 2004 CLE Workshop Series

Osinbajo Y "The Law of Evidence and Information Technology" 2004 CLE Workshop Series 21-32

Plant E-Commerce

Plant R E-Commerce: Formulation of Strategy (Prentice-Hall Upper Saddle River NJ 2000) 


\section{Reporter 1999 IBAQ}

Reporter "Commentaries from the Bar" 1999 Irish Bar Association

Quarterly July 18

Reporter 1999 SBJ

Reporter "Case reviews" 1999 (6) Scotland Bar Journal 6

Rowley 2002 JMIP

Rowley J "Synergy and Strategy in E-commerce" 2002 (20) Journal of

Marketing Intelligence and Planning 215-220

Turban Electronic Commerce

Turban E Electronic Commerce: A Managerial Perspective (Prentice-Hall New York 2000)

Westland and Clark Global Electronic Commerce

Westland JC and Clark TH Global Electronic Commerce: Theory and Case Studies (MIT Press Cambridge 2000)

Zwass IJEC

Zwass V "Electronic commerce: structures and issues" 1996 International Journal of Electronic Commerce 3-23

\section{Register of legislation}

Civil Evidence Act 1964 (UK)

Civil Jurisdiction and Judgement Act 1982 (UK)

Computer Fraud and Abuse Act 1991 (USA)

Computer Misuse Act 1990 (UK)

Data Protection Act 1984 (UK)

Draft Bill on Cyber Crimes

Draft Bill on Electronic Transactions

Electronic Communications Privacy Act 1988 (USA)

Electronic Communications Privacy Act 1988 (USA)

Evidence Act 1965 (UK)

Nigerian Evidence Act 1945

Pre-shipment of Exports Act 1996 
Pre-shipment of Imports Act 1993

Price Control Act 1990

Sale of Goods Act 1979

South Australian Evidence Act 1929

Supply of Goods (Implied Terms) Act 1973 (UK)

Telecommunication and Postal Offences Act 1995

Trade Malpractices (Miscellaneous Offences) Act 1992

Weight and Measures Act 1977

\section{Register of court cases}

African Petroleum v Owodunni [1991] 8 NWLR 351

Anyeabosi v RT Briscoe [1987] 3 NWLR 84

Bradesh Co Ltd v Arthur (unreported)

Bradesh v Arthur (unreported)

Chanco Leasing SPA v Rediffusion Ltd [1987] 1 FTLR 207

DTM Ltd v Hydranautics [1981] 2 Lloyd's Report 2211

Edwards v Skyview [1964] 1 WLR 399

Entores Ltd v Miles Far East Corporation [1953] 2 QB 327

Esso Petroleum v Customs and Excise Commissioners [1976] 1WLR 1

Harvela Investments Ltd v Royal Trust Company of Canada Ltd [1986] AC 207

King v State Ex Rel Murdock Acceptance Corporation [1996] 22 F2d 39

Quenerdine v Cole (1883) 32 WL 185

$R v$ Brown [1996] 1 All ER 545

Robinson v Graves [1935] 1 KB 579

Shaktas On-line Services Ltd v Burrough [1999] (unreported)

Smith v Hughes (1871) LR 6 QB 597

Specht v Netscape [2002] (unreported)

St Alban's City and District Council v International Computers Ltd [1996] 4 All

ER 481

Subramanian v Public Prosecutor [1956] WLR 965

Thornton v Shoe Lane Parking [1971] 2 QB 163

Yesufu v ACB [1976] 4 SC 1

\section{Register of international instruments}


Brussels Convention on Jurisdiction and Enforcement of Judgments in Civil and Commercial Matters 1958

Rome Convention on the Law Applicable to Contractual Obligations 1980

UNICITRAL Model law on Electronic Commerce 1996

\section{List of abbreviations}

ch chapter(s)

IT Information Technology

NECC National Electronic Commerce Council

NITDA National Information Technology Development Agency

OECD Organisation for Economic Co-operation and Development S section(s) 